\title{
Gibberellin Induces Shoot Growth and Flowering in Nonprecooled Derooted Bulbs of Tulip (Tulipa gesneriana L.)
}

\author{
Marian Saniewski', Ludwika Kawa-Miszczak', \\ Elzbieta Wegrzynowicz-Lesiak' and Hiroshi Okubo ${ }^{2}$
}

\author{
'Research Institute of Pomology and Floriculture, Pomologic'zna 18, 96-100 \\ Skierniewice, Poland \\ Laboratory of Horticultural Science, Faculty of Agriculture, Kyushu University 46-01. \\ Fukuoka 812-8581, Japan \\ (Received October 30, 1998 and accepted Now mber 6, 1998)
}

\begin{abstract}
Effect of gibberellic acid $\left(\mathrm{GA}_{3}\right)$ at a concentration of $200 \mathrm{mgl}^{+}$on shoot growth and flowering in nonprecooled derooted tulip bulbs cvs. Gudoshnik and Apeldoom was investigated. In control nonprecooled derooted bulbs flower bud blasting occurred and no growth of stem was observed. GA greatly induced shoot growth and flowering. The stimulatory effect of gibberellin on shoot growth and fowering in nonprecooled derooted bulbs was much stronger than in case of nonprecooled rooted bulbs (previously published results). $\mathrm{GA}_{3}$ stimulated also stem growth after excision of flower bud with upper part of leaves and scales. It is probable that excision of all roots in nonprecooled bulbs decreases the level of abscisic acid and exogenous gibberellic acid is more effective in comparison to nonprecooled rooted bulbs. Or it is also possible that better penetration and uptake of gibberellin take place after removal of roots. It seems that gibbercllin can substitute for cold requircment and that interaction of exogerous gibberellin with endogenous auxin controls stem growth.
\end{abstract}

\section{INTRODUCTION}

Tulip bulbs, with terminal buds containing a complete flower, require a period of 12-16 weeks of low temperature treatment for floral stalk elongation (De Hertogh, 1974). It is well known that during the cooling of the tulip bulbs the amount of free gibberellins increases (Aung and De Hertogh, 1967; 1968; De Hertogh et al., 1971; Van Bragt, 1971; Aung and Rees, 1974; Hanks and Rees, 1980). Hanks and Rees (1980) found two peaks of activity of gibberellin-like substances in tulips sampled at intervals from October (planting time) until the following April (flowering time). The first one occurred in December or in early-January samples, before the cold requirement was completed, and the second peak occurred around the time of rapid shoot extension and flowering found in roots, scales, leaves, stems, daughter bulbs and in flowers. Recently, however, Rebers et al. (1995) suggested that there was no direct correlation between cold-stimulated growth and a change in endogenous GA status in sprouts or basal plates of tulip bulbs during cold storage.

Saniewski and De Munk (1981) and Banasik and Saniewski (1985) concluded that elongation of all internodes in cooled tulip bulbs is promoted by auxin produced in leaves and flower buds, and that the auxin-release or response system was stimulated by

\footnotetext{
${ }^{1.2}$ Correspondence to either author. 'Tel: +48-46-33-2021, Fax: +48-46-33-3228, E-mail: msanicw@insad.isk.skierniewice.pl-Tel: +81-92-642-2828, Fax: +81-92-642-2829, E-mail: hokubo@agr.kyushu-u.ac.jp
} 
gibberellins. Recently it has been suggested that the elongation of all internodes in tulips is controlled by auxin and gibberellins (Okubo and Uemoto, 1985; 1986; Okubo et al., 1986; Saniewski, 1989). Okubo and Uemoto (1986) suggested that two different gibberellins are involved in controlling the elongation of the lower and upper internodes of tulip flower stalk. Kawa and Saniewski (1986) showed that gibberellic acid had a strong stimulatory effect in increasing the length and fresh weight of pistil isolated from uncooled tulip bulbs but to lesser degree in the case of cooled bulbs, cultured in vitro. Saniewski (1989) suggested that gibberellins produced during the cooling of bulbs play an important role in the flower bud development, mostly pistil growth, and other gibberellins are synthesized during shoot growth and, together with auxin, control the stem elongation in tulips. Rebers et al. (1995) also suggested that in tulip GAs are involved in the stalk clongation response.

Exogenously applied gibberellins cannot substitute for cold treatment of uncooled tulip bulbs but do for only partially cooled bulbs and stimulate shoot growth and flowering (Van Bragt and Zijlstra, 1971; Rudnicki et al., 1976; Van Bragt and Van Ast, 1976; Cocozza Talia and Stellacci, 1979; Hanks, 1984; 1985; Jones and Hanks, 1984).

In the present work the stimulatory effect of gibberellin on tulip shoot growth and flowering in nonprecooled derooted tulip bulbs is documented.

\section{MATERIALS AND METHODS}

\section{Plant materials}

Tulip bulbs cvs. Gudoshnik and Apeldoom, with a circumference of $10-11 \mathrm{~cm}$, after lifting were stored at $18-20^{\circ} \mathrm{C}$ until used for experiments between November $10-22$ (nonprecooled bulbs). After the removal of dry scales the following experiments were conducted.

\section{Experiment 1}

All roots were excised and bulbs were kept on petri dishes 1) with distilled water or 2) with gibberellic acid $\left(\mathrm{GA}_{3}\right)$ at a concentration $200 \mathrm{mgl}^{-1}$. In a second group all roots were excised and the upper part of the scales, together with flower bud and the upper part of the leaves at the level of the flower bud, were cut and the bulbs were kept on petri dishes 3) with distilled water or 4) with $\mathrm{GA}_{3}$ at a concentration of $200 \mathrm{mgl}^{-1}$.

\section{Experiment 2}

All roots were excised and the apices of sprouted leaves were treated as follows: a) untreated, b) lanolin on leaf apex, c) IAA $0.1 \%$ in lanolin on leaf apex, d) lanolin after removal of $2 \mathrm{~mm}$ leaf apex, or e) IAA $0.1 \%$ in lanolin after removal of $2 \mathrm{~mm}$ leaf apex. The treated bulbs were kept on petri dishes 1) with distilled water or 2) with $\mathrm{GA}_{3}$ at a concentration of $200 \mathrm{mgl}^{-1}$.

In both experiments 15 bulbs per treatment were used and every experiment was repeated twice. Newly appeared roots were removed daily. During the experiments the shoot growth and flowering were measured and photographed. 
Table 1. Effect of $\mathrm{GA}_{2} 200 \mathrm{mgl}$ - on shoot growth and flowering of nonprecooled derooted bulbs.

\begin{tabular}{|c|c|c|c|c|c|c|c|c|c|c|}
\hline \multirow[t]{2}{*}{ Treatment } & \multicolumn{5}{|c|}{$\begin{array}{l}\text { Length of sprout (first leaf) or *stem } \\
\text { with flower bud (mm) }\end{array}$} & \multicolumn{5}{|c|}{ Lerugth of internode $(\mathrm{mm})$ on Dee. 22} \\
\hline & $\begin{array}{c}\text { Nov. } \\
11\end{array}$ & $\begin{array}{c}\text { Nov. } \\
30\end{array}$ & $\begin{array}{l}\text { Dec. } \\
3\end{array}$ & $\begin{array}{c}\text { Dec. } \\
9\end{array}$ & $\begin{array}{l}\text { Dec. } \\
22\end{array}$ & 1st & 2nd & $3 \mathrm{rd}$ & $4 \mathrm{~h}$ & Total \\
\hline \multicolumn{11}{|c|}{$\begin{array}{l}\text { Roots removed } \\
\text { cv. Gudoshnik }\end{array}$} \\
\hline water & 23.3 & 34.9 & 46.4 & 64.7 & 81.5 & & - - & & & \\
\hline $\mathrm{GA}_{3}$ & 28.1 & 51.2 & 71.1 & 118.4 & $* 243.4$ & 32.0 & 25.9 & 30.9 & 86.5 & 175.3 \\
\hline \multicolumn{11}{|l|}{ cv. Apcldoorn } \\
\hline water & 26.9 & 39.1 & 48.3 & 60.9 & 73.6 & & -2 & & & \\
\hline $\mathrm{CiA}_{\mathrm{i}}$ & 31.1 & 50.5 & 66.2 & 98.1 & $* 215.7$ & 14.1 & 17.9 & 27.2 & 95.2 & 154.4 \\
\hline \multicolumn{11}{|c|}{$\begin{array}{l}\text { Roots removed and flower bud together with upper parl of } \\
\text { leaves and scales excised } \\
\text { cv. Gudoshnik }\end{array}$} \\
\hline water & 7.1 & 10.8 & 15.6 & 27.9 & 37.0 & & - & & & \\
\hline $\mathrm{G}_{3}$ & 8.3 & 17.4 & 29.6 & 33.7 & 36.8 & 31.3 & 16.5 & 7.4 & 11.1 & 66.3 \\
\hline \multicolumn{11}{|l|}{ cv. Apcldoorn } \\
\hline water & 6.5 & 10.8 & 16.6 & 23.5 & 30.0 & & - & & & \\
\hline GA & 9.4 & 18.5 & 30.2 & 34.5 & 37.0 & 26.5 & 16.7 & 11.4 & 11.7 & 66.3 \\
\hline
\end{tabular}

\section{RESULTS AND DISCUSSION}

\section{Experiment 1}

The shoot growth of nonprecooled derooted tulip bulbs was very small in both cultivars, only sprouting of leaves was observed and flower bud blasting took place (Table 1, Fig. 1). Gibberellic acid at a concentration of $200 \mathrm{mgl}$ ' caused the breaking dormancy and induced the shoot growth and flowering in nonprecooled derooted tulip bulbs. GA also stimulated stem growth aftcr cxcision of the flower bud and the upper part of the leaves at the level of the flower bud. Thus, independent of the presence or absence of a flower bud in nonprecooled derooted tulip bulbs gibberellin stimulated stem growth, but was much less effective in cases where flower bud and upper part of leaves were excised. It scems that exogenously applied gibberellin stimulates pistil growth, and interaction of exogenous gibberellin with endogenous auxin is responsible for elongational growth of stem.

\section{Experiment 2}

I $\mathrm{A}$ 0.1\% applied on leaf apex did not affect shoot growth of nonprecooled tulip bulbs kept on the water or treated with $\mathrm{GA}_{3}$ (Täble 2, Fig. 2). It was suggested previously that the elongation of all internodes in precooled tulip bulbs is controlled by interaction of auxin and gibberellin (Okubo and Uemoto, 1985; 1986; Okubo et al., 1986; Sanicwski, 1989). The stimulatory cffect of gibberellin on shoot growth in nonprecooled derooted 

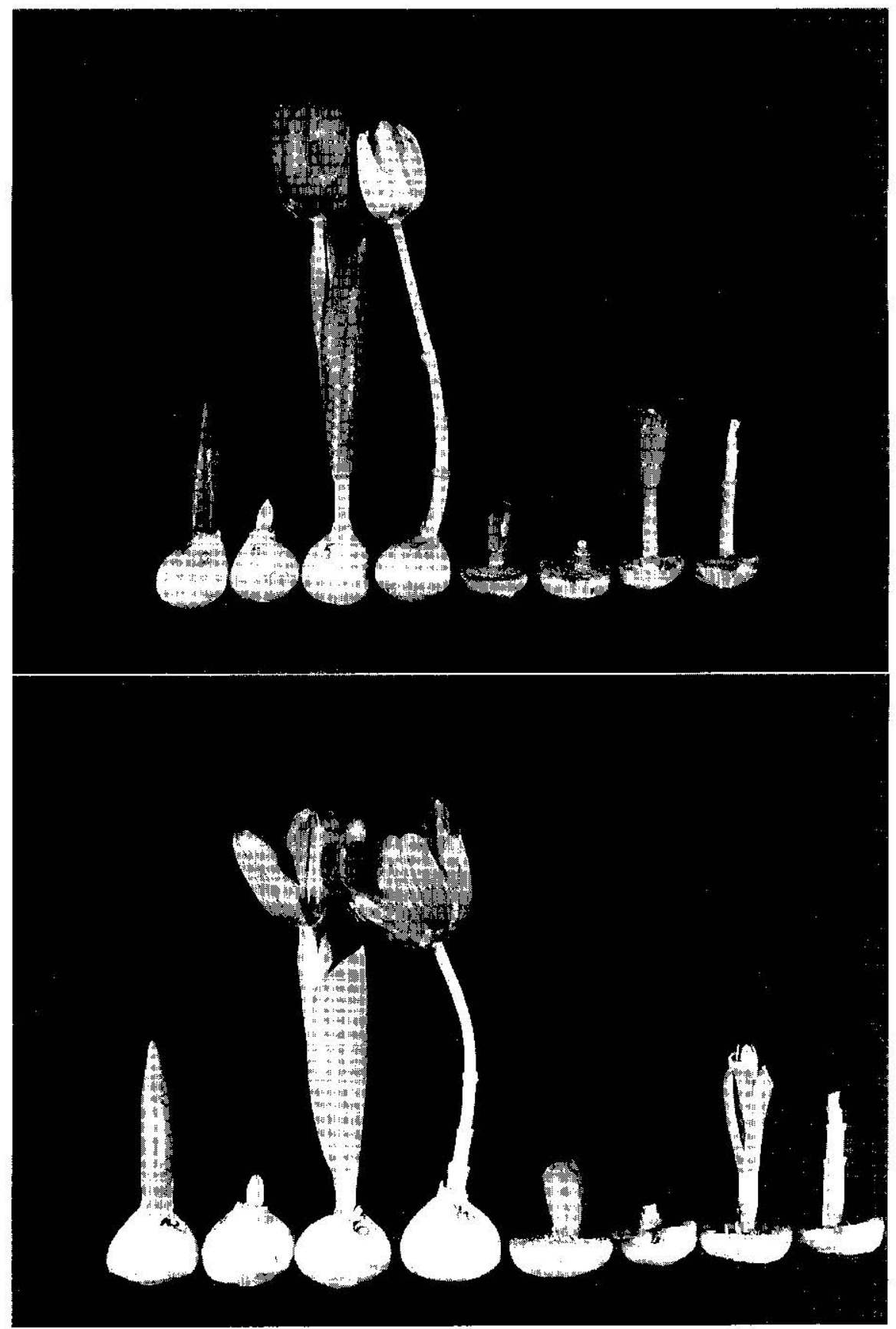

Fig. 1. Effect of $\mathrm{GA}_{2} 200 \mathrm{mg}{ }^{1}$ on shoot growth and flowering of nonprecooled derooted bulbs. Lpper; $c v$. Gudoshnik, lower; $\mathrm{ev}$. Apeldoorn. Treatment was on November 22 and the plants were photographed on December 17, either with leaves (Left) or after removal of all leaves (Right) before photography. From left to right, control, distilled water-no growth of stern and flower bud blasting can be observed, $\mathrm{GA}_{1}$-stimulatory effect on shool growth and flowering, control, distilled water-small growth of leaves and stem after cut of Ilower bud together with leaves and scales, GA $\mathrm{G}_{n}$-stimulatory effect on stem growth can be observed. 
Table 2. Effect of IAA $0.1 \%$ treatment on the lear apex on shoot growth and flowering of nomprecooled derooted bulbs cv. Gudoshtrik kept in water and $\mathrm{GA}_{3} 200 \mathrm{mgl}^{-1}$

\begin{tabular}{|c|c|c|c|c|c|c|c|c|}
\hline \multirow[t]{2}{*}{ Treatment } & \multicolumn{3}{|c|}{ 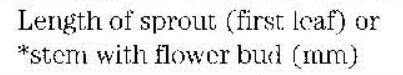 } & \multicolumn{5}{|c|}{ Length of internode $(\mathrm{mm})$ on Dec. 12} \\
\hline & Dec.2 & Dec.8 & Dec.12 & $1 \mathrm{sit}$ & 2nd & $3 \mathrm{rid}$ & Ath & Totäl \\
\hline \multicolumn{9}{|l|}{ intreated } \\
\hline waler & 43.7 & 57.5 & 75.7 & & -2 & & & \\
\hline GA: & 66.9 & 93.4 & $* 205.0$ & 19.5 & 18.6 & 20.9 & 75.8 & 134.8 \\
\hline \multicolumn{9}{|c|}{ Lawotin on intact leaf apex } \\
\hline waller & 49.4 & 63.8 & 84.1 & & $-*$ & & & \\
\hline $\mathrm{GA}_{\mathrm{A}, 3}$ & 69.5 & 98.9 & $* 229.1$ & 25.6 & 22.0 & 26.3 & 83.9 & $1 \overline{5} 7.8$ \\
\hline \multicolumn{9}{|c|}{ IAAO $1 \%$ ow intact leerf apex } \\
\hline water & 63.1 & 82.7 & 103.5 & & -4 & & & \\
\hline $\mathrm{GA}_{3}$ & 82.6 & 117.6 & *180.9 & 24.5 & 18.6 & 18.4 & 63.5 & 124.0 \\
\hline \multicolumn{9}{|c|}{ Larolin after remotal of $2 \mathrm{~mm}$ lear apex } \\
\hline water & 43.8 & 57.9 & 75.9 & & $--^{2}$ & & & \\
\hline $\mathrm{G} \Lambda_{3}$ & 60.5 & 87.6 & *232.5 & 31.8 & 23.6 & 26.8 & 86.6 & 168.8 \\
\hline \multicolumn{9}{|c|}{ MA $0.7 \%$ after removal of $2 \mathrm{~mm}$ lear apex } \\
\hline water & 56.3 & 77.9 & 99.3 & & -2 & & & \\
\hline $\mathrm{GA}_{3}$ & $7 \% .2$ & 118.2 & $* 209.5$ & 30.0 & 21.6 & 23.8 & 73.7 & 149.1 \\
\hline
\end{tabular}

No stem growth, and flower bud blasting.

tulip bulbs was much stronger than in case of nonprecooled rooted bulbs (Rudnicki et al., 1976). In our experiments we used $\mathrm{GA}_{3}$ but $\mathrm{GA}_{4}, \mathrm{GA}_{1}, \mathrm{GA}_{4}, \mathrm{GA}_{13}, \mathrm{GA}_{24}$ and $\mathrm{GA}_{34}$ were identified in both non-cold cooled tulip bulb sprouts (Rebers, 1992; Rebers et al., 1994b; 1995). GA was the major gibbercllin, while $\mathrm{G} \Lambda_{1}, \mathrm{G} \Lambda_{4}$ and $\mathrm{GA}_{34}$ were present in lower amounts. Rebers et al. (1995) suggested that in tulip, gibbcrellins are not the cold-induced trigger but are involved in the stalk elongation response, as was shown by the inhibition of this elongation by the GA biosynthesis inhibitors, ancymidol and paclobutrazol, and the reversal of this effect by applied GA (Shoub and De Hertogh, 1974; Saniewski, 1989; Rebers et al., 1994a). Rebers et al. (1995) showed the higher level of $\mathrm{GA}_{4}$ and its inactivation product $\mathrm{GA}_{34}$ only in growing floral stalks of cooled bulbs, and the absence of a significant quartitative accumulation of $\mathrm{GA}_{1}$ and suggest that $\mathrm{GA}_{4}$ is probably involved in the floral stalk elongation of tulip.

It is possible that excision of all roots in nonprecooled tulip bulbs decreases the level of abscisic acid ( $\mathrm{ABA}$ ) and/or exogenous gibberellic acid is more effective in comparison to intact nomprecooled rooted bulbs. The presence of abscisic acid in tulips is well documented (Aung and De Hertogh, 1979; Singh el al., 1979; Syrtanova et al., 1975; Terry et al., 1982) and low temperature treatment decreases the amount of ABA (Syrtanova et al., 1973; Rakhimbayev et al., 1978; Aung and De Hertogh, 1979). Aung and De Hertogh (1979) suggested that probable sites of abscisic acid biosynthesis in tulip bulb are the developing bulblets, basal plate and roots, since the ABA level is high in these organs and low in the scales and shoot. The inhibitory cffect of ABA on pistil and stem growth in tulips was also well documented (Sanjewski et al., 1990). It is also possible to consider that after excision of roots in nonprecooled tulip bulbs better penetration and uptake of gibberellin take place and they are more effective in stimulation of shoot growth in 


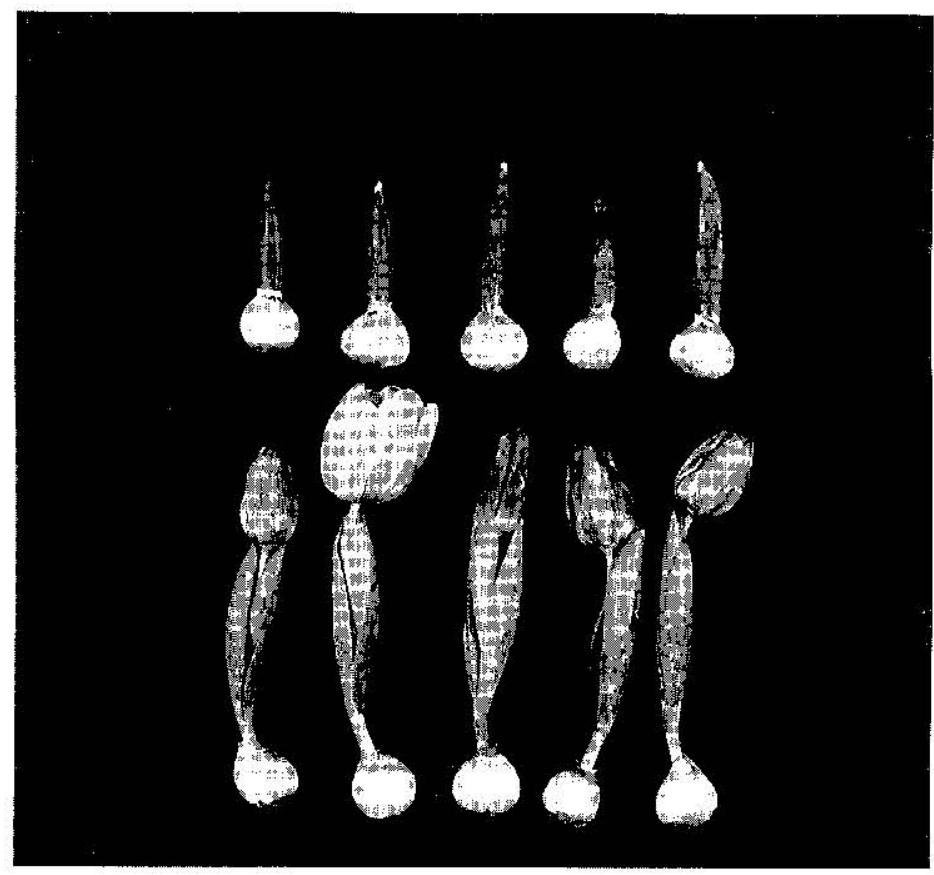

Fig. 2. Hilfect of leaf apcx IAA 0.1\% treatment on the shoot growth and flowering of nomprecooled derooted bulbs cv. Gudoshuik kept in water and $\mathrm{GA}_{3} 200 \mathrm{mgl}^{-1}$. Upper row; bulbs kept in water, lower row: bulbs kept in $\mathrm{GA}_{3}$. From left to right; untreated, lanolin on leaf apex, IAA on leaf apcx, lanolin after removal of 2 mm leaf apex, IAA after removal of $2 \mathrm{~mm}$ leaf apex. Treatments applied on November 19, photographed on December 21.

comparison to nonprecooled rooted bulbs. Our results indicate that gibberellin can substitute for the cold requirement of tulip bulbs.

\section{ACKNOWLEDGMENTS}

The stay of Marian Saniewski at Kyushu University, Fukuoka, Japan was supported by the invitation fcllowship program for research in Japan, Japan Society for the Promotion of Science.

\section{REFFRENCES}

Aung, L. II. and A. A. De Hertogh 1967 The occurrence of gibberellin-like substances in tulip bulbs (Tulipa sp.). Plant Cell Physiol, 8: 201-205

Aung, L. H. and A. A. De Hertogh 1968 Gibberellin-like substances in non-cold and cold treated tulip bulbs (Tulipa sp.). In "Biochemistry and Physiology of Plant Growth Substances" cd. by F.

Wightman and G. Setterfield, Runge l’ress, Ottawa, pp. 943-956 
Aung, L. H. and A. A. Dc Hertogh 1979 Temperature regulation of growth and endogenous abscisic acid-like content of Tulipa gesneriana L. Plant Physiol., 63:1111-1116

Alug, L. H. and A. R. Rees 1974 Changes in endogenous gibberellin levels in Tulipa bulblets during ontogeny. J. Exp. Bot., 25: 745-751

Banasik, L. and M. Saniewski 1985 The effect of different auxins on tulip stalk elongation. Acta Hortic., 167: 193-204

Cocozza Talia, M. and P. Stellacci 1979 A research on the effect of gibberellin upon tulip flowering. Acta Hortic., 91: 167-172

De Herlogh, A. 1974 Principles for forcing lulips, hyacinths, daffodils, Easter lilies and Dutch irises. Scientia Hortic., 2: 313-355

De Fertogh, A. A., L. H. Aung, A. E. Einert and G. L. Staby 1971 Aspects of extractable gibberellin-like substances from Tuipa gesneriana ì. Acta Honic., $\mathbf{2 3}: 90-95$

Hanks, G. R. 1984 Factors affecting the resporse of tulips to gibberellins. Scientia Hortic., 23: 379-390

Hanks, G. R. 1985 The response of $9^{\circ} \mathrm{C}$-tulips to gibberellins. Scientia Hortic., 27: 153-161

Hanks, G. R. and A. R. Rees 1980 Growth substances of tulip: the activity of gibberellin-like substances in field-grown tulips from planting until flowering. Z, Pflanzenphysiol., 98: 213223

Jones, S. K. and G. K. Hanks 1984 Treatment of tulips with gibberellic acid by vacuum infiltration. $J$. Hort. Sci., 59:241-252

Kawa, L. and M. Saniewski 1986 The effect of gibberelic acid and abscisic acid on tulip pistil growth in vitro. Acta Hortic., 177: 129-133

Okubo, H, and S. Jemoto 1985 Changes in endogenous gibberellin and auxin activities during first internode elongation in tulip flower stalk. Plant Cell Phystol., 26: $709-719$

Okubo, H. and S. Uemoto 1986 Changes in endogenous gibberellin during internode elongation of tulip flower stalk as affected by light condition.s. J. Japan. Soc: Hort. Sci., 55: 215-220

Okubo, H., S. Shiraishi and S. Uemoto 1986 Factors controlling elongation of the last internode in tulip flower stalk. J. Japan. Soc. Hort. Sci., 55: 320-325

Rakhimbayev, I. R., G. A. Syrtariova and V. F. Solomina 1978 The effect of cold treatment on the level of biological activity of endogenous growth regulators of tulip bulbs. Plant Physiol (Russ.)., 25: $249-253$

Rebers, M. 1992 The role of gibberellins in the cold requirement of tulip. Acta Hortic., 325: 253-258

Rebers, M., G. Romeijn, E. Knegt and 1. H. W. van der Plas 1994a Effects of exogenous gibbereilins and paclobutrazol on floral stalk growth of tuljp sprouts isolated from cooled and non-cooled tulip bulbs. Physiol. Plant, 92: 661-667

Rebers, M., E. Vermeer, E. Knegt, C. J. Shelton and L. H. W. van der Plas 1994b Gibberellins in tulip bulb sprouts during storage. Phytochemistry, 36: 269-272

Rebers, M., E. Vermeer, E. Knegt, C. J. Shelton and L. H. W. van der Plas 1995 Gibberellins level and cold-induced floral stalk elongation in 1,ulip. Physiol Plant., 94: 687-691

Rudnicki, R. M., J. Nowak and M. Saniewski 1976 The effect of gibberellic aciri on sprouting and flowering of some tulip cultivars. Scientia Hortic., 4: 387-397

Sanicwski, M. 1989 The use of paclobutrazol, an inhibitor of gibberellin biosynthesis, for study of hormonal control of tulip stem elongation. Bull. Pol. Acad. Sci. Biol. Sci., 37: 55-64

Sanicwski, M. and W. J. De Munk 1981 Hormonal control of shoot elongation in tulips. Scientia Hortic.; 15: $363-372$

Saniewski, M., L. Kawa and E. Wegrzynowicz 1990 The effect of abscisic acid on pistil and stem growth in tulips. Prace. Inst. Sad. i Kuiac. Seria B, 15: 95-104

Shoub, J. and A. A. De Hertogh 1974 Effects of ancymidol and gibberellins $A_{\text {: }}$ and $A_{1+;}$ on Tulipa gesneriana L. cv. Paul Richter during development in the greenhouse. Scientia Hortic., 2: 55-67

Singh, B. N., E. Galston, W. Dashek and D. C. Walton 1979 Abscisic acid levels and metabolism in the leaf epidermal tissue of Tulipa gesneriana L. and Commelina communis L. Planta, 146: $1435-1438$

Syrtanova, G. A., I. R. Rakhimbayev and W. l. Kefeli 1975 Native growth inhibitor of tulip. Plant Physiol (Russ.)., 22: 165-169 
Syrtanova, G. A., R. 'Turetzkaja ant I. R. Rakhinbayev 1973 Natural auxins and inhibitors in dormant and growing tulip bulbs. Plast Physiol (Russ.), 20: 1133-1136

Terry, P. H., J. H. Aung and A. A. De Hertogh 1982 Identification of abscisic acid in Tulipa gesneriana L. by gas-liquid chromatography and mass spectroscopy. Plont Phigsiol, 70: 1574-1576

Van Bragt, J. 1971 Endogenous gibberellin levels and floral stalk elongation in tulip cv. Apeldoorn. Landbouwwetenschoppen Gent, 36: 1301-1307

Van Bragt, J. and K. J. van Ast. 1976 Substitution of the cold requirenent of tulip cv. Apeldoorn by GA;. Sciontia Hortic., 4: 117-12i

Van Bragl, J. and F. A. Zijlstra 1971 Effects of gibberellins on flowering of 1ulip ev. Apeldoorn. Z. Pflanzenphysiol, 64 : 139-144 